\title{
BUSINESS TRANSFER ECOSYSTEM IN CROATIA - MISSING COMPONENTS AND INTERACTIONS
}

\section{Mirela Alpeza, Slavica Singer, Petra Mezulić Juric}

(1) Faculty of Economics, J.J. Strossmayer University in Osijek, Osijek, Croatia,

(2) Faculty of Economics, J.J. Strossmayer University in Osijek, Osijek, Croatia

(3) Faculty of Economics, J.J. Strossmayer University in Osijek, Osijek, Croatia

\author{
Mirela Alpeza \\ Faculty of Economics \\ University in Osijek J.J. Strossmayer, Osijek, Croatia, \\ malpeza@efos.hr \\ Article info \\ Paper category: Preliminary paper \\ Received: 18. 8. 2016. \\ Accepted: 21. 9. 2016. \\ JEL classification: $\mathrm{L}_{5} 3$, L21
}




\begin{abstract}
Business transfer is an important issue that the European Commission has been actualising since the early 1990s, when the first recommendations for the improvement of national business transfer ecosystems of the EU countries were created. Neglecting business transfer as a critical phase in the development of a company can have significant negative implications for companies, their owners and wide network of stakeholders. Business transfer is a particularly important topic for the Croatian economy where more than 5,30o businesses with around 57,000 employees represent a risk group whose owners underestimate the complexity and longevity of the business transfer process. The aim of this paper is to analyse the structure and quality of the business transfer ecosystem in Croatia. For this purpose, secondary research and a qualitative study in the form of interviews with representatives of key stakeholders were conducted. The Croatian business transfer ecosystem is benchmarked to the national business transfer ecosystems of Spain, Finland, Sweden and France, based on the data collected through the EU project BTAR. The research results indicate low level of development, interconnection and complementarity of individual components of the business transfer ecosystem in Croatia. Policy recommendations for improving the quality of the business transfer ecosystem in Croatia were identified.
\end{abstract}

\title{
Keywords:
}

business transfer; ecosystem; small and medium enterprises 


\section{WHAT IS BUSINESS TRANSFER, WHY IS IT IMPORTANT AND TO WHOM?}

Long-term sustainability of small and medium enterprises largely depends on the continual ability to innovate and therefore any disruptive event which endangers it should be carefully managed. One of such disruptive events is a change in ownership / management of a company, like the withdrawal of the company owner / founder from the business. Business transfer process is most commonly associated with the retirement of the owner of the company, but retirement is just one of the reasons. The trend of earlier withdrawal from the business due to changes in entrepreneur's professional interests, a good opportunity to sell the company, or the desire to start a new entrepreneurial venture, is increasingly present in developed countries (Van Teeffelen, 2012). Emergencies, such as illness or death of the company owner, represent bad circumstances of business transfer, especially when those situations were not preceded by adequate preparation.

Due to the high rate of failure in the implementation of the process of business transfer in small and medium enterprises in the European Union, the European Commission has been monitoring the quality of national business transfer ecosystems in member countries for more than 20 years, and making recommendations for the improvement of the support system to policy makers at the national level. The European Commission's position is that systematic support to companies in this phase of the life cycle is equally important as the support to start-up companies, because taking over an existing company represents an equally important way of entering into entrepreneurship. Studies show a significantly higher rate of survival of companies that have gone through business transfer in relation to start-ups, higher revenues and profits of transferred companies compared to start-up companies, and a major shift in new employment (Geerts et al., 2004; KfW, 2009). Business transfer represents a unique opportunity for companies for strategic renewal and transformation of business, to which younger entrepreneurs are more inclined than those who are nearing retirement.

The complexity of business transfer is the result of legal, financial, tax, organisational and psychological aspects of this process. Business transfer in most cases requires multi-year, thorough and timely preparation. Many healthy and successful companies experience tectonic changes when they go through the business transfer process, and these changes may ultimately significantly undermine the market position of the company. Healthy financial situation, competitive product range, good company reputation - none of these are a guarantee of successful passing through the process of business transfer. Some of the elements that increase the chances for success are commitment of the owner to this problem, involvement of family members in making the decision about the future of the company, two-way communication with respect and appreciation of attitudes of everyone involved, and timely opening of this topic. 


\section{POLICY CONTEXT OF BUSINESS TRANSFER IN THE EUROPEAN UNION}

Business transfer of small and medium enterprises represents a big challenge in the EU countries, where it is estimated that each year around 450,000 companies with around 2 million employees go through this process. It is further estimated that the issue of business transfer is not adequately approached in approximately $15^{\circ}, 000$ companies, which jeopardizes around 600,000 jobs (European Commission, 2011).

European Commission has been monitoring the quality of business transfer ecosystems in EU member states since 1994. Based on the assessment of the situation in individual member states and the identified key pillars of support that should be developed, the guidelines for activities of national line ministries and other relevant institutions for the creation of a support system for owners of small and medium enterprises in the business transfer process are identified.

The first recommendations to member states from 1994 (European Commission, 1994) were focused on improving legal, fiscal and administrative environment for business transfer, including the need for raising awareness among business owners on the importance of timely designed business transfer process in order to save jobs.

In 1998, the European Commission in its report on the transfer of small and medium enterprises stated that recommendations from 1994, were not fully implemented in improving national ecosystems for business transfer (especially outside of interventions in simplification of the legal system) and the importance of informing and educating business support actors was emphasized (European Commission, 1998).

In 2002, a special group of experts for business transfer made a report about the progress in implementing 1998 recommendations and the slow process of their implementation in national policies was again confirmed.

In 2006, the concept of business transfer as a new beginning and not as the end of business life cycle was explicitly introduced in the Communication of European Commission along with a warning that thousands of good SMEs are disappearing each year because they are not able to overcome obstacles / problems related to business transfer. At the same time, member states were invited to introduce special national policies and programmes for establishing a supportive ecosystem for business transfer, by paying special attention to raising awareness of the complexity of business transfer process and establishing transparent platforms for selling / buying businesses (European Commission, 2006).

A comprehensive EU policy intervention in building supportive ecosystem for business transfer of SMEs in member states was introduced through the Think Small First principle of the Small Business Act from 2008, which is advocating for creation of environment in which entrepreneurs and family businesses can thrive and 
entrepreneurship is rewarded. Business transfer is also specifically emphasized in the Principle 4 (Make public administration responsive to SMEs needs); Principle 7 (Help SMEs to benefit more from the opportunities offered by the Single market) and Principle 10 (Encourage and support SMEs to benefit from the growth of markets).

In 2011 monitoring report on the implementation of the Small Business Act, member states were invited to create transparent virtual markets (platforms) as a meeting place for business transfer actors (sellers and buyers). Lack of awareness of the complexity of the business transfer process and knowledge how to deal with it were again emphasized as important obstacles to the effective business transfer process and member states were invited to deal with them through their policy interventions.

Additionally, a comprehensive analysis of recommendations related to business transfer ecosystems presented by the European Commission in 2011 („Business Dynamics - Start-ups, Business Transfers and Bankruptcy") explicitly introduced the life cycle approach for integrating different phases of venturing (start-up, business transfer and closing the business) in order to get a better platform for designing coherent policies. A lack of systematic monitoring of business transfer in member states was identified as the result of different definitions of business transfer.

In the last monitoring report from 2013, the European Commission urges national governments (specifically relevant ministries) and other institutional stakeholders to engage in creating coherent supportive ecosystems for business transfer. Recommended interventions for creating supportive national business transfer ecosystems are: $1 /$ raising the awareness of company owners about the importance of timely preparation for the success of business transfer, and of everyone who, based on their profession, should provide support in that process; $2 /$ simple and tax-relieved legislative framework for business transfer; 3 / creating virtual platforms for connecting buyers and sellers of companies; 4/ creating financial instruments for easier takeover and purchase of companies; $5 /$ strengthening advisory support in the process of business transfer.

In „Entrepreneurship 2020 Action Plan“, the European Commission re-enforces integrative framework based on understanding inter-connectedness between different phases of the business life cycle as a platform for designing coherent policies in order to build a supportive ecosystem in which business transfer is happening.

\section{THE IMPORTANCE OF THE ISSUE OF BUSINESS TRANSFER IN CROATIA}

In Croatia, there is no statistical record of the conducted business transfer processes. Insight into the issue of business transfer in Croatia is provided by two studies - the Global Entrepreneurship Monitor - GEM research, which has been carried out in 
Croatia since 2002, and the Business Transfer Barometer research, conducted in 2015. GEM research is the world's largest survey on entrepreneurship, which, among other indicators, monitors the causes of discontinuation of business activities (Table 1.).

Table 1.: Reasons for discontinuation of the business, $2014-\%$ of exits

\begin{tabular}{|l|r|r|}
\hline $\begin{array}{c}\text { Reasons for discontinuation } \\
\text { of the business }\end{array}$ & Croatia & \multicolumn{2}{|c|}{ EU } \\
\hline Opportunity to sell & 0.83 & 3.32 \\
Business not profitable & 33.6 & 33.24 \\
Problems getting finance & 23.55 & 11.5 \\
Another job or business & 12.95 & 11.62 \\
opportunity & 1.44 & 5.18 \\
Exit was planned in advance & 2.51 & 6.08 \\
Retirement & 17.87 & 23.83 \\
Personal reasons & 7.26 & 5.22 \\
An incident & & \\
\hline
\end{tabular}

Source: GEM data base, 2014, prepared by S. Singer

Problems with the profitability are the major reason for discontinuation of the businesses in Croatia and in EU (on the level of one third of discontinuation cases). Lack of finance is much more frequent as a reason for discontinuation in Croatia than in EU, what is important information in discussion about the quality of ecosystem in which small businesses operate. Another important differentiated feature is how many exits were planned in advance - despite planned exits are among the three least reasons for discontinuation (besides retirement and opportunity to sell) in Croatia as well as in EU, there are almost 2,5 times more such cases in EU than in Croatia. This difference confirms the need for activities related to rising awareness of the complexity and longevity of business transfer process in EU, but especially in Croatia, as well as designing supportive ecosystem for it.

Besides of the reasons for business discontinuation, GEM provides insight in the health of business dynamics by collecting information on intensity of entry and intensity of exits from business activities. Low intensity of exits can be an indicator of status quo, or of a healthy economy, but high intensity of exits can indicate lack of successful business strategies and/or lack of a supportive business ecosystem (e.g. complicated regulatory framework, lack of appropriate financial instruments, lack of innovativeness...) (Singer et al., 2016).

The Business Transfer Barometer research started with identification of small and medium sized companies whose majority owners are of $55^{1}$ or more years of age in the population of all companies with limited liabilities in Croatia. In 2014

1 According to numerous studies (e.g. Varamaki, 2013) 55 years of age is considered a turning point in which it is necessary to start thinking about business transfer, since it is a process that usually takes several years. 
there were 16,590 such companies in Croatia $^{2}$. These companies employ 179,087 employees, which is a $16.1 \%$ share in the total number of people employed in limited liability companies, and generate revenue of EUR 15,2 billion (18.9\% of the total revenue generated by all limited liability companies in Croatia). Using the sample of 200 respondents from the population of businesses with limited liabilities ${ }^{3}$ whose majority owners have $55^{+}$years of age provided a possibility to estimate that more than 5,300 companies with around 57,000 employees represent a risk group, whose owners underestimate the complexity and longevity of business transfer process. The research has shown that $32 \%$ of company owners that belong to generation $55^{+}$are not aware of the inevitability of change of their role in the management and ownership function in the company (Figure 1.).

Figure 1.: Awareness of owners about the change of role in the management and ownership function in the company (Your role in the company will change in the next...?)

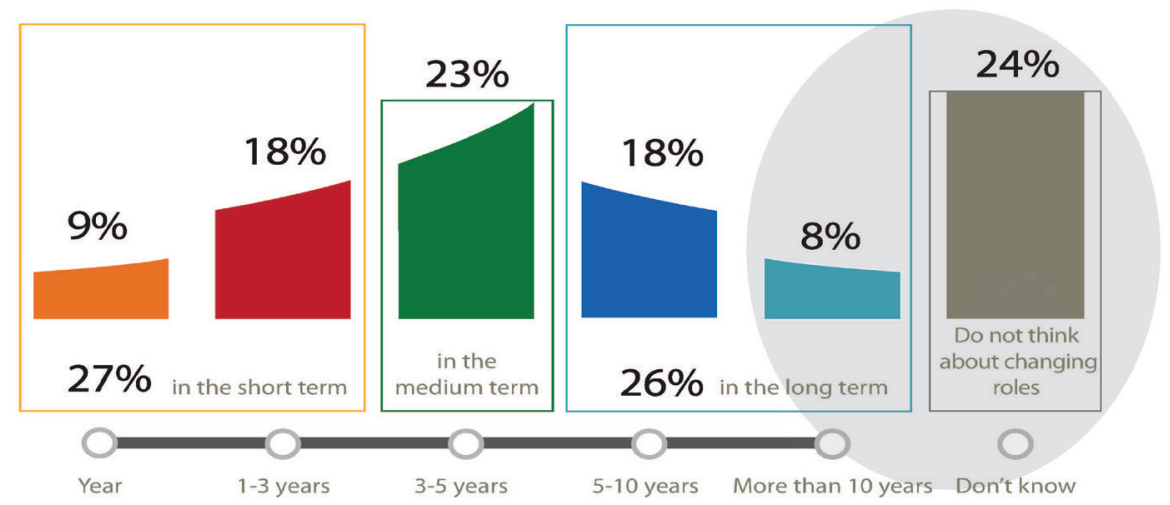

Source: Alpeza, M., Grubišić, N., Mikrut, M.: „Business Transfer Barometer Croatia”, GEPOR - SMEs and Entrepreneurship Policy Center, Zagreb, 2015

Business Transfer Barometer research in Croatia has shown that 22\% of entrepreneurs underestimate the duration of the business transfer process and believe that less than a year is enough time for the transfer to take place, while $50 \%$ believe that it would take 1-3 years. (Figure 2.).

2 Source: Bisnode Croatia, based on the data annual financial documents of SMEs in 2014.

3 Within the Business Transfer Barometer research, 200 respondents who are majority owners of small and medium companies in Croatia, and have 55 or more years of age were surveyed. The sampling frame consisted of limited liability companies (Ltd.) with a minimum of one employee and with minimum annual revenue of 15,000 EUR. The survey was conducted using CATI (telephone survey) and CAWI (online survey) methods. The sample is representative by the company size for the SME sector. 
Figure 2.: Perception of the time required for business transfer

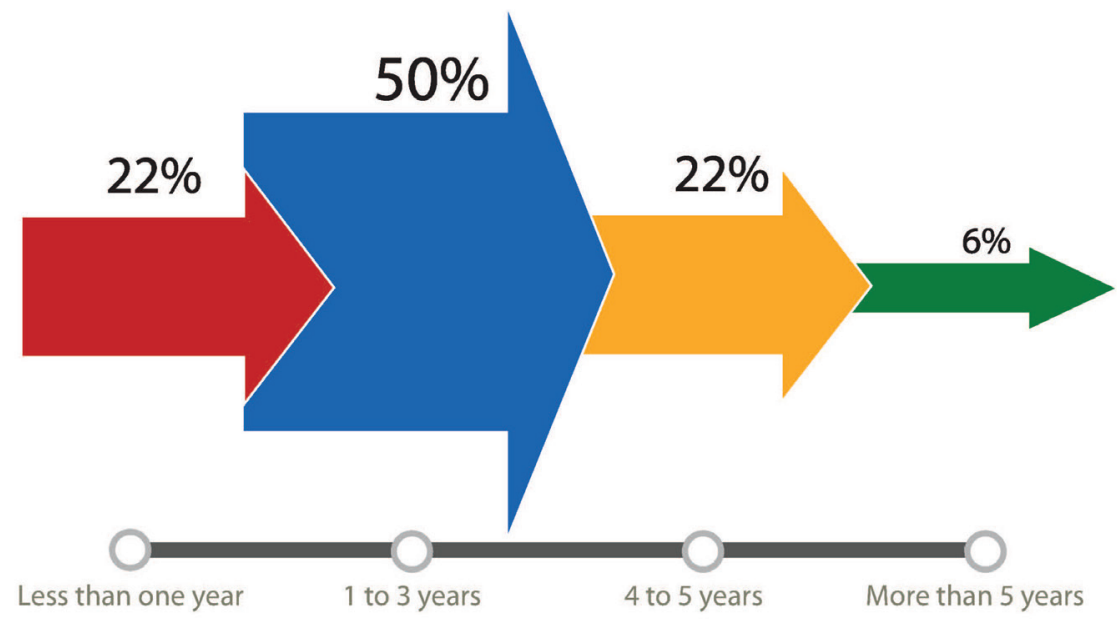

Source: Alpeza, M., Grubišić, N., Mikrut, M.: „Business Transfer Barometer Croatia“, CEPOR - SMEs and Entrepreneurship Policy Center, Zagreb, 2015

Among entrepreneurs aged $55^{+}$there are $65 \%$ of those who believe that they will need support with various aspects related to business transfer. The most needed is in the activities of the technical implementation of the business transfer $(4,3 \%)$, company valuation $(4,2 \%)$, and harmonization of company and family interests when making the decision on the transfer of business (36\%) (Figure 3.).

Figure 3.: Aspects of business transfer for which owners aged $55^{+}$expect they will need advisory support

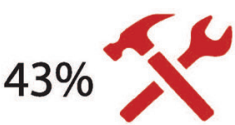

TECHNICAL IMPLEMENTATION OF THE BUSINESS TRANSFER

\section{$42 \%$}

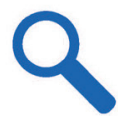

COMPANY VALUATION

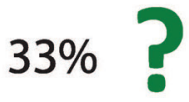

HOW TO START THE BUSINESS TRANSFER PROCESS

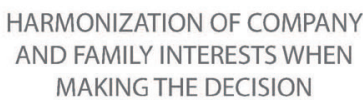

MAKING THE DECISION

Source: Alpeza, M., Grubišić, N., Mikrut, M.: „Business Transfer Barometer Croatia“, CEPOR - SMEs and Entrepreneurship Policy Center, Zagreb, 2015

One of the characteristics of the business owners generation $55^{+}$in Croatia is that most of their companies were established in the 1990 s ( $76 \%)$, and that owners of companies are also their founders, without personal experience of participation in the business transfer process (Figure 4.). 
Figure 4.: Ownership profile of business owners generation $55^{+}$
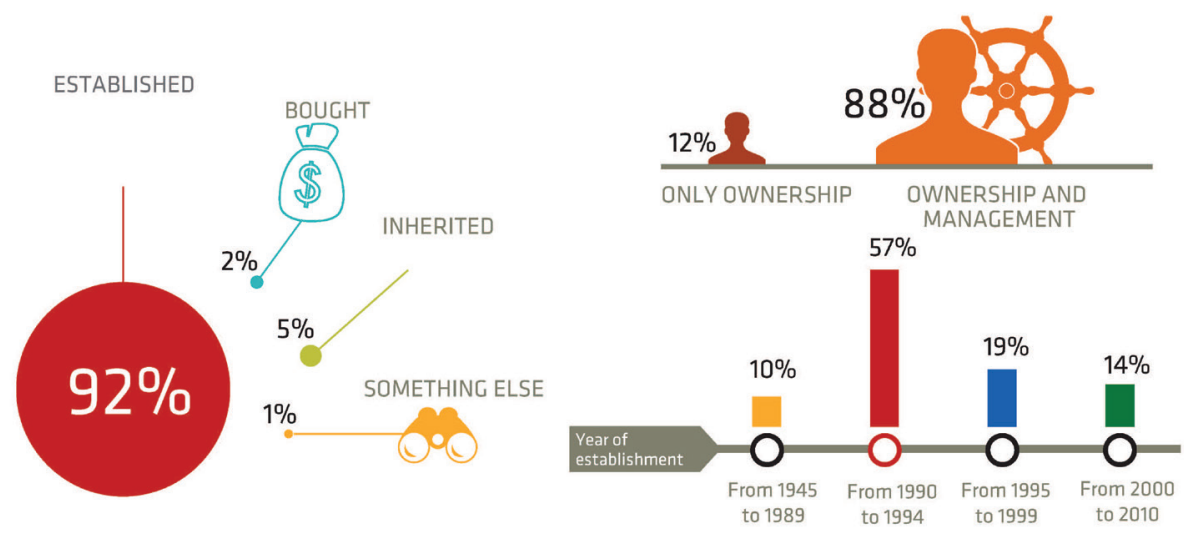

Source: Alpeza, M., Grubišić, N., Mikrut, M.: „Business Transfer Barometer Croatia“, GEPOR - SMEs and Entrepreneurship Policy Center, Zagreb, 2015

The results of Business Transfer Barometer research from 2015 indicate that $31 \%$ of all small and medium enterprises in Croatia are owned (and in majority cases managed) by the entrepreneurs aged $55^{+}$who will be faced with the issue of business transfer in the coming period. It is estimated that 5,300 businesses with around 57,000 employees represent a risk group for business transfer. The research results indicate that $32 \%$ of business owners aged $55^{+}$do not see that their role in ownership / management will be changed in next 10 years and that $72 \%$ of business owners think that time required for business transfer is less than 3 years. These are warning information which should be taken into account by policy makers, as well as other stakeholders responsible for the quality of the business transfer ecosystem in Croatia.

\section{COMPONENTS OF THE BUSINESS TRANSFER ECOSYSTEM}

Business transfer is not happening in a vacuum, independently of market conditions, regulatory framework and business infrastructural support system. When analysing the actors and factors of influence on business transfer processes, the main elements of business transfer ecosystem were identified as: market and economic conditions, tax policy, buyers, sellers, financial institutions and advisors (Van Teeffelen, 2012). Ecosystem is not a static concept, but rather a dynamic one, with the constant need to improve the ecosystem, bearing in mind the interconnectedness of its components (adapted from Isenberg, 2010). The goal of ecosystem is to enable individual actors to expand their capabilities beyond their own boundaries through collaboration with other actors (Singer et al., 2015).

Business transfer ecosystem is in the function of successful implementation of the business transfer process whose key actors are buyers and sellers, while the 
function of other components of the ecosystem is to provide support and increase the level of success of the key actors in the implementation of the business transfer process (Figure 5.).

Figure 5.: The key elements and content of the business transfer ecosystem

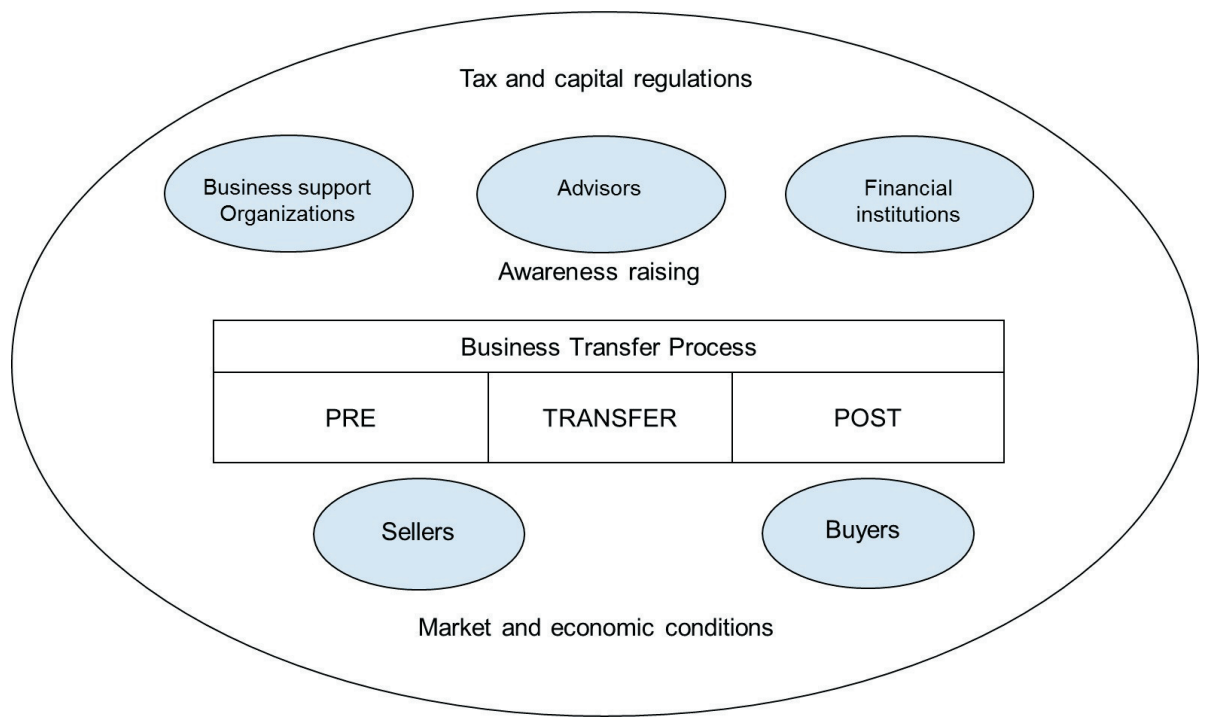

Source: Varamaki, E.; Viljamaa, A.; Tall, J., Lansiluoto, A. (2014), adapted from Van Teeffelen, L. (2012)

Analysis of the business transfer ecosystem indicates a significant influence of the government policy setting on most of the components, from tax and capital regulations, market and economic conditions and awareness raising actions to business support organizations, financial institutions and advisors whose activity can also be stimulated by favourable government initiatives related to business transfer friendly environment (Van Teeffelen, 2012).

The buyer and the seller are the essential ingredients for business transfer processes, and other components (business support organizations, advisors and financial institutions) can make significant positive impact on the quantity and quality of business transfer processes. Buyers and sellers, as the key actors of the business transfer process, often lack the necessary knowledge and experience to implement the business transfer process since it is most often a process they are facing once in a lifetime, especially in the case of aging entrepreneurs. The above indicates the importance of advisors in the business transfer ecosystem, whose role is to provide advisory support to buyers and sellers in solving organisational, financial, tax, legal and emotional issues (European Commission, 2011).

In addition to knowledge and experience, also present on the seller's side is the problem of insufficient preparation and planning of the business transfer pro- 
cesses, which, because of their complexity, often last for several years. Activities for raising awareness of owners of companies about the importance of timely preparation and planning are important for increasing the success rate of business transfer. Financial institutions, banks in particular, play the key role in financing business transfers, and a negative decision on financing of acquisitions, that is, purchase of companies is among the most frequently cited causes of failure in business transfer (European Commission, 2002). In some countries (e.g. Spain), tax policy can represent a significant aggravating circumstance for the implementation of business transfer, which additionally emphasizes the importance of timely planning and preparation.

\section{BUSINESS TRANSFER ECOSYSTEM IN CROATIA}

For the purpose of research of content and quality of the business transfer ecosystem in Croatia, interviews were conducted with 20 national stakeholders - representatives of institutions, which, according to their missions, constitute the components of the ecosystem: financial institutions, providers of advisory support, business support organisations, and potential sellers and buyers of companies. Interviews were conducted during 2015 , based on a prepared checklist with questions that make up the outline of the interview. The methodology of iterative clinical interviews suggested by Schein (1993) was applied in the conducting of interviews, in which the researcher interacts with an internal member of the organisation in which the research is carried out and invests significant effort to clarify the purpose and significance of the research. In this way, respondents find benefits in the implementation of the research for themselves, organisation and environment in which they operate, and their motivation to contribute to the research process and results is increased. In this research, the respondents were informed about the results of the Business Transfer Barometer research in Croatia, as well as the recommendations of the European Commission for the development of business transfer ecosystem in EU countries.

Secondary research was used to analyse the activities aimed at promoting the importance of business transfer in Croatia, as well to analyse general market and economic conditions, legislation, and tax system. The situation analysis of the national business transfer ecosystem in Croatia prepared within the EU project: BTAR - Business Transfer Awareness Raising4 was used for the purposes of this research. In the framework of the BTAR project, national ecosystems in other four EU countries were investigated (Finland, France, Spain and Sweden) and

4. The BTAR project is financed with the funds from the EU CIP programme in the 2014-2016 period. Project leader is the Seinäjoki University of Applied Sciences from Finland, and the project partners are Grenoble School of Management from France, Jaume I University from Spain, Faculty of Economics of the J.J. Strossmayer University of Osijek from Croatia and University of Skövde from Sweden. 
the results were used to compare Croatia with the design of their respective business transfer ecosystems ${ }^{5}$.

The research results and information gathered through the conducted secondary research and primary qualitative research shown in Table 2 provide a parallel comparison of national business transfer ecosystems in Croatia, France, Sweden, Finland and Spain. Results of the comparison of the Croatian business transfer ecosystem with those in the aforementioned countries indicate weak development of the national business transfer ecosystem in Croatia in almost all components of the ecosystem.

\subsection{Sources of information on SME business transfer markets (buyers and sellers)}

In Croatia, a low level of transparency of the market for business transfer of small and medium enterprises is evident, as well as the lack of data on the number of active buyers and sellers, and the absence of channels through which contact could be established and preconditions for implementation of the business transfer process created. In contrast to Croatia, in other countries with which the comparison was made, there are virtual markets and it is possible to estimate the number of active sellers and buyers of small and medium enterprises.

\subsection{Financial institutions involved in business transfers}

Results of the analysis indicate the absence of financial instruments for the purchase of companies in Croatia, which significantly decreases the number of potential buyers of companies. In other observed countries, availability of funding sources is not identified as an obstacle to the implementation of the business transfer process.

Availability of expert advice

Lack of availability of expert advisory support for SME business transfer is also identified in Croatia, especially for the segment of micro companies. In this component Croatia significantly lags behind the business transfer ecosystems of developed countries in which there is a wide availability of both public and private consultants, and company owners regard experts as important stakeholders of the business transfer process.

5 In each country case data was collected by local research teams made of senior and junior academic scholars familiar with the ownership transfer phenomenon. A total of 16 researchers participated in the data collection, using the same conceptual framework in each country. As a result, the country ecosystems were explored by using of both primary (e.g. interviews, expert testimonials, field observations) and secondary (reports, barometers, statistics, etc.) data to build each country case (Viljamaa et al., 2015). 


\subsection{Business support organisations}

Public business support institutions in Croatia do not recognise the specific challenges of the business transfer process for entrepreneurs and, accordingly, they are not developing services that would provide support in the process - neither at national nor local level. In other observed countries, there is space for improvement of both the services and cooperation, but it is evident that there is a developed support system.

\subsection{Awareness raising activities}

Activities aimed at raising awareness of entrepreneurs about the complexity and longevity of the business transfer process, and the possibilities of entering entrepreneurship by taking over a business venture are at a very low level in Croatia. The responsible institutions at the national, regional and local level are not initiating such activities, and they are rarely becoming involved as support in cases when awareness raising activities are initiated by private organisations.

\section{$5 \cdot 5$. Key legislation and tax laws effecting business transfers}

Unlike other EU countries, especially Spain, in which the tax burden in the case of inheritance of a company ranges from around 95\%, the legislative framework for business transfer in Croatia can be given a relatively positive grade.

The legal framework for business transfers in Croatia consists of the following laws: Labour Law, Crafts Act, Law on Local and Regional Self-government, Civil Obligations Act, Companies Act, Inheritance Act, Accounting Act and Family Law. Business transfer of crafts is regulated in 2013 with the "new" Crafts Law that represents favourable legal framework for business transfer in different occasions: death of the owner of the craft, retirement and transfer of the ownership of the craft to third parties. In case of company inheritance, the Companies Act stipulates that business shares can be inherited. The Inheritance Act also recognizes legal and testamentary inheritance, where in the first inheritance order the company is inherited by children and spouse, in equal parts. This law is regulating the inheritance process in detail, especially in case of testamentary inheritance. According to the Law on Local and Regional Self-government, the tax on inheritance and gifts is not paid by spouse, blood relative in a straight line, adopted children and adoptive parents of the deceased or the person giving the company. The inheritance of business shares for others is subject to tax on inheritance at the rate of $5 \%$. In this case, the tax base is the market value of financials and other assets, after deduction of debts and expenses relating to the property on which tax is paid.

In case of selling the company, the cost of services of notary public is the only compulsory expense. Additional provisional costs are the lawyer costs and the cost of 
changing the owner of the company which has to be published in the Official Gazette. The money that the seller gains by the selling the company is considered as capital gain, and as such it is not taxed in Croatia.

Unlike Croatia, other EU countries (e.g. France) use the tax system to encourage planning of the business transfer during the lifetime of the company owner, since tax burdens are more substantial if the issue of the company's future is dealt with after the owner's death. Also, in France and Spain there is an endeavour to protect the interests of employees that work in companies undergoing business transfer through the regulatory framework, and it is expected from owners to timely inform employees about the changes in the ownership structure of the company.

Based on the above, it can be concluded that 5 out of 6 aforementioned components of the national business transfer ecosystem in Croatia do not have a supporting effect for business transfer processes of small and medium enterprises. Also, given the underdevelopment of the key components of the ecosystem, there is no awareness of the necessity of their mutual cooperation, coordination and complementarity of activities.

Table 2.: Benchmarking of the Croatian national business transfer ecosystems to France, Finland, Spain and Sweden

\begin{tabular}{|c|c|c|c|c|c|}
\hline $\begin{array}{c}\text { Business } \\
\text { Transfer } \\
\text { Ecosystem } \\
\text { Components }\end{array}$ & Croatia & France & Finland & Spain & Sweden \\
\hline $\begin{array}{l}\text { Key legisla- } \\
\text { tion and tax } \\
\text { laws effect- } \\
\text { ing business } \\
\text { transfers }\end{array}$ & $\begin{array}{r}\text { Legislation } \\
\text { does not } \\
\text { represent a } \\
\text { barrier for } \\
\text { business } \\
\text { transfer: } \\
\text { No inheri- } \\
\text { tance and gift } \\
\text { tax for spouse } \\
\text { and children; } \\
\text { No tax on } \\
\text { selling shares } \\
\text { of companies }\end{array}$ & $\begin{array}{r}\text { Sellers have } \\
\text { an interest } \\
\text { in planning } \\
\text { a transfer } \\
\text { carefully, for } \\
\text { the taxation is } \\
\text { complex and } \\
\text { fiscal conse- } \\
\text { quences can } \\
\text { vary; } \\
\text { owner of a } \\
\text { SME has to } \\
\text { inform all } \\
\text { employees } \\
\text { about owner- } \\
\text { ship transfer } \\
\text { at minimum } \\
\text { two months } \\
\text { before the } \\
\text { transfer takes } \\
\text { place }\end{array}$ & $\begin{array}{r}\text { Relatively } \\
\text { stable legisla- } \\
\text { tive environ- } \\
\text { ment that } \\
\text { does not in- } \\
\text { hibit business } \\
\text { transfers }\end{array}$ & $\begin{array}{r}\text { Tax on in- } \\
\text { heritance and } \\
\text { donations is } \\
\text { transferred } \\
\text { to the regions } \\
\text { and each of } \\
\text { them has a } \\
\text { specific rate } \\
\text { and applica- } \\
\text { tion (min } \\
95 \%) ; \\
\text { the transferor } \\
\text { and the buyer } \\
\text { are required } \\
\text { to provide } \\
\text { information } \\
\text { to the legal } \\
\text { representa- } \\
\text { tives of their } \\
\text { respective } \\
\text { employees }\end{array}$ & $\begin{array}{r}\text { No inheri- } \\
\text { tance and gift } \\
\text { tax; } \\
\text { the regulatory } \\
\text { framework } \\
\text { is technically } \\
\text { complicated } \\
\text { and aimed at } \\
\text { large compa- } \\
\text { nies }\end{array}$ \\
\hline
\end{tabular}




\begin{tabular}{|c|c|c|c|c|c|}
\hline $\begin{array}{c}\text { Business } \\
\text { Transfer } \\
\text { Ecosystem } \\
\text { Components }\end{array}$ & Croatia & France & Finland & Spain & Sweden \\
\hline $\begin{array}{l}\text { Sources of in- } \\
\text { formation on } \\
\text { SME business } \\
\text { transfer mar- } \\
\text { kets (buyers } \\
\text { and sellers) }\end{array}$ & $\begin{array}{r}\text { No matching } \\
\text { platforms } \\
\text { for business } \\
\text { transfer of } \\
\text { SMEs } \\
\text { No transpar- } \\
\text { ent data on } \\
\text { buyers and } \\
\text { sellers }\end{array}$ & $\begin{array}{r}\text { About } 50,000 \\
\text { potential } \\
\text { firms to be } \\
\text { transferred } \\
\text { each year; } \\
\text { Several online } \\
\text { market places } \\
\text { for SMEs are } \\
\text { available; } \\
\text { Lack of trans- } \\
\text { parency - one } \\
\text { of the key } \\
\text { problems on } \\
\text { the SME busi- } \\
\text { ness transfer } \\
\text { market; } \\
\text { Buyers spend } \\
\text { on average } \\
\text { 13 months in } \\
\text { the business } \\
\text { transfer pro- } \\
\text { cess; } \\
\text { Sellers do } \\
\text { not know } \\
\text { the busi- } \\
\text { ness transfer } \\
\text { process and } \\
\text { are badly } \\
\text { prepared } \\
\text { The financing } \\
\text { opportuni- } \\
\text { ties offered } \\
\text { to buyers are } \\
\text { well devel- } \\
\text { oped; } \\
\text { Interest-free } \\
\text { loans without } \\
\text { guarantees } \\
\text { are available } \\
\text { for indi- } \\
\text { viduals from } \\
\text { a public insti- } \\
\text { tution; } \\
\text { There are } \\
\text { public pro- } \\
\text { grammes to } \\
\text { encourage } \\
\text { individuals to } \\
\text { buy firms; } \\
\text { Private equity } \\
\text { financing is } \\
\text { well devel- } \\
\text { oped }\end{array}$ & $\begin{array}{r}\text { A number } \\
\text { of platforms } \\
\text { are available, } \\
\text { although the } \\
\text { volumes of } \\
\text { offers are not } \\
\text { great; } \\
\text { About a fifth } \\
\text { of aging en- } \\
\text { trepreneurs } \\
\text { are planning } \\
\text { to implement } \\
\text { family suc- } \\
\text { cession } \\
\text { Business } \\
\text { transfers of } \\
\text { small firms } \\
\text { are a verylo- } \\
\text { cal phenom- } \\
\text { enon } \\
\text { Issues of } \\
\text { valuation, } \\
\text { asking high } \\
\text { price and } \\
\text { financing are } \\
\text { important } \\
\text { Private equity } \\
\text { financing not } \\
\text { very well } \\
\text { developed } \\
\text { and rarely } \\
\text { available for } \\
\text { business } \\
\text { transfers; } \\
\text { Banking } \\
\text { sector de- } \\
\text { velopments } \\
\text { have led to } \\
\text { increasing } \\
\text { difficulties } \\
\text { in financing } \\
\text { small busi- } \\
\text { ness trans- } \\
\text { fers; } \\
\text { State-owned } \\
\text { financing } \\
\text { organization } \\
\text { involved in } \\
\text { 50\% of busi- } \\
\text { ness transfers }\end{array}$ & $\begin{array}{r}\text { Clear efforts } \\
\text { to develop } \\
\text { business } \\
\text { transfer mar- } \\
\text { kets; } \\
\text { Online plat- } \\
\text { forms with } \\
\text { a variety of } \\
\text { services exist } \\
\text { - one of them } \\
\text { offers integral } \\
\text { advice service } \\
\text { with the web } \\
\text { portal show- } \\
\text { ing supply } \\
\text { and demand; } \\
\text { the number } \\
\text { of transfers } \\
\text { is expected to } \\
\text { grow; } \\
\text { the dura- } \\
\text { tion and } \\
\text { complexity } \\
\text { of the busi- } \\
\text { ness transfer } \\
\text { process is the } \\
\text { main obstacle }\end{array}$ & $\begin{array}{r}\text { Main actors } \\
\text { in financ- } \\
\text { ing business } \\
\text { transfers } \\
\text { are banks, } \\
\text { state owned } \\
\text { organization } \\
\text { (ALMI) and } \\
\text { business } \\
\text { angels; Loans } \\
\text { dominate as } \\
\text { instrument } \\
\text { for financ- } \\
\text { ing business } \\
\text { transfers; } \\
\text { Lack of lo- } \\
\text { cal financial } \\
\text { capital and } \\
\text { availability of } \\
\text { risk capital } \\
\text { for small } \\
\text { firms busi- } \\
\text { ness transfer }\end{array}$ \\
\hline
\end{tabular}




\begin{tabular}{|c|c|c|c|c|c|}
\hline $\begin{array}{c}\text { Business } \\
\text { Transfer } \\
\text { Ecosystem } \\
\text { Components }\end{array}$ & Croatia & France & Finland & Spain & Sweden \\
\hline $\begin{array}{l}\text { Business } \\
\text { support or- } \\
\text { ganisations }\end{array}$ & 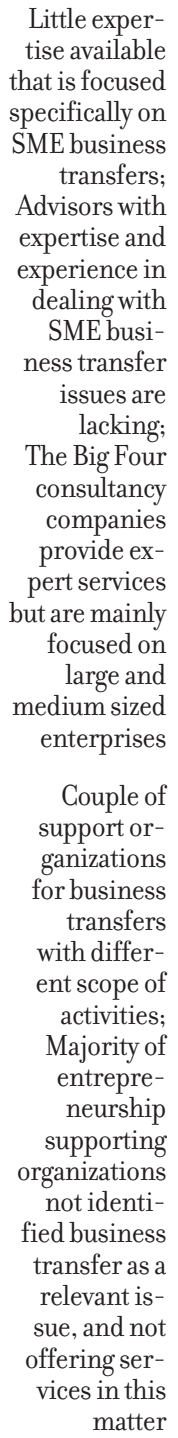 & $\begin{array}{r}\text { Private sector } \\
\text { advisors and } \\
\text { their interests } \\
\text { can be di- } \\
\text { vided into two } \\
\text { main catego- } \\
\text { ries: big firms } \\
\text { and SMEs; } \\
\text { SME business } \\
\text { transfer mar- } \\
\text { ket advisory } \\
\text { services very } \\
\text { fragmented in } \\
\text { nature; } \\
\text { Many in- } \\
\text { dependent } \\
\text { consulting } \\
\text { companies } \\
\text { offer services } \\
\\
\text { tional levels }\end{array}$ & $\begin{array}{r}\text { External } \\
\text { advisors are } \\
\text { important } \\
\text { stakeholders } \\
\text { in business } \\
\text { transfers for } \\
\text { sellers and } \\
\text { buyers; } \\
\text { Entrepre- } \\
\text { neurs unde- } \\
\text { rutilize com- } \\
\text { petent experts } \\
\text { and seek } \\
\text { expertise at a } \\
\text { too late phase } \\
\text { of the busi- } \\
\text { ness transfer } \\
\text { process; } \\
\text { Small firms } \\
\text { tend to favour } \\
\text { accountants, } \\
\text { banks and } \\
\text { auditors as } \\
\text { advisors }\end{array}$ & $\begin{array}{l}\text { Business sup- } \\
\text { port organi- } \\
\text { zations can be } \\
\text { divided into } \\
\text { two catego- } \\
\text { ries: public } \\
\text { organizations } \\
\text { and founda- } \\
\text { tions/associa- } \\
\text { tions; A coop- } \\
\text { eration effort } \\
\text { has led to a } \\
\text { creation of a } \\
\text { plan for busi- } \\
\text { ness transfer } \\
\text { support and } \\
\text { continuity }\end{array}$ & $\begin{array}{r}\text { Many support } \\
\text { organizations } \\
\text { for general } \\
\text { business is- } \\
\text { sues, yet busi- } \\
\text { ness transfers } \\
\text { represent a } \\
\text { side issue and } \\
\text { formal coop- } \\
\text { eration is on a } \\
\text { low level; } \\
\text { The busi- } \\
\text { ness support } \\
\text { organizations } \\
\text { mainly focus } \\
\text { on financial } \\
\text { support; } \\
\text { There is some } \\
\text { cooperation } \\
\text { among local } \\
\text { actors }\end{array}$ \\
\hline
\end{tabular}




\begin{tabular}{|c|c|c|c|c|c|}
\hline $\begin{array}{c}\text { Business } \\
\text { Transfer } \\
\text { Ecosystem } \\
\text { Components }\end{array}$ & Croatia & France & Finland & Spain & Sweden \\
\hline $\begin{array}{l}\text { Awareness } \\
\text { raising activi- } \\
\text { ties }\end{array}$ & $\begin{array}{r}\text { Awareness } \\
\text { raising activi- } \\
\text { ties are still } \\
\text { undeveloped; } \\
\text { Annual con- } \\
\text { ferences on } \\
\text { family busi- } \\
\text { nesses and } \\
\text { round table } \\
\text { discussions } \\
\text { are held but } \\
\text { mainly with } \\
\text { the focus on } \\
\text { family busi- } \\
\text { ness; } \\
\text { First national } \\
\text { research on } \\
\text { business } \\
\text { transfers } \\
\text { conducted in } \\
2015\end{array}$ & $\begin{array}{r}\text { Each year } \\
\text { many the- } \\
\text { matic events } \\
\text { about SME } \\
\text { business } \\
\text { transfers are } \\
\text { organized by a } \\
\text { variety of ac- } \\
\text { tors for both } \\
\text { sellers and } \\
\text { buyers; } \\
\text { The level of } \\
\text { awareness } \\
\text { raising activi- } \\
\text { ties is quite } \\
\text { high, but on } \\
\text { the regional } \\
\text { level room for } \\
\text { improvement } \\
\text { can be found }\end{array}$ & $\begin{array}{r}\text { Variety of } \\
\text { activities: } \\
\text { activation let- } \\
\text { ters, events, } \\
\text { calls and } \\
\text { visits, busi- } \\
\text { ness transfer } \\
\text { barometers } \\
\text { mostly tar- } \\
\text { geted for } \\
\text { aging entre- } \\
\text { preneurs }\end{array}$ & $\begin{array}{r}\text { A number } \\
\text { of activi- } \\
\text { ties: training } \\
\text { workshops } \\
\text { and other } \\
\text { events and } \\
\text { information } \\
\text { materials.; } \\
\text { Events are of- } \\
\text { ten regionally } \\
\text { organized }\end{array}$ & $\begin{array}{r}\text { Courses, } \\
\text { booklets and } \\
\text { brochures } \\
\text { available, as } \\
\text { well as a You- } \\
\text { Tube video } \\
\text { for either } \\
\text { aging entre- } \\
\text { preneurs or } \\
\text { SME owners }\end{array}$ \\
\hline
\end{tabular}

Source: adapted from Singer et al.: "Business transfer ecosystems: from assumption-based to evidence based design", RENT Conference Zagreb, 2015; Situation analysis of the national business transfer ecosystems in Croatia, Spain, France, Finland and Sweden conducted within the BTAR EU project

\section{CONCLUSION, IMPLICATIONS AND POLICY RECOMMENDATIONS}

Given the important role that small and medium enterprises have in the Croatian economy (68\% share in employment, $52.1 \%$ of the total revenue), it is necessary, at the level of policies and programmes, to monitor the specific problems related to the development of this sector. Business transfer represents one of the specific problems that will be increasingly present in the future. The Business Transfer Barometer research has highlighted the impact that the companies which are faced with the business transfer process have on the small and medium enterprise sector in Croatia (16,590 companies whose majority owners have 55 or more years of age, which have more than 179,087 employees, and a share of $16.1 \%$ in the total number of employees and $18.9 \%$ of the total revenue generated by all limited liability companies in Croatia).

This paper has identified a low level of development of the key components that should comprise an efficient business transfer ecosystem in Croatia, whose role should be to build and connect the key components of support for the owners of small and medium enterprises in the implementation of the business transfer process. The conclusions about the weak development of the business transfer ecosystem 
are based on the analysis of the components of the national business transfer ecosystem in Croatia and the comparison of the ecosystem with those of other four EU countries: France, Spain, Sweden and Finland. The underdevelopment of individual components of business transfer ecosystem in Croatia is accompanied with the absence of interaction and cooperation between the components of the ecosystem.

In order to develop a support system for business transfer and facilitate the sustainability of small and medium enterprises after the retirement of their owners, and to enable a safer starting of entrepreneurial activity for young entrepreneurs through taking over (purchasing) of entrepreneurial ventures, involvement of all the relevant institutions is necessary, especially those responsible for creating measures and policies that will provide support to small and medium enterprises in the business transfer process. For this purpose, it is important to act immediately to implement the recommendations of the European Commission from 2013, whose importance has been confirmed by the Business Transfer Barometer research and the conclusions of this paper:

- Launching campaigns aimed at raising awareness of owners of small and medium enterprises with 55 and more years of age about the importance of timely preparation for business transfer;

- Lunching campaigns aimed to potential entrepreneurs about starting entrepreneurial activity through taking over (purchasing) of companies;

- Creating financial instruments for easier accessibility of purchasing (taking over) companies;

- Creating virtual exchanges that will allow connecting sellers and buyers of companies;

- Strengthening advisory support (lawyers, mediators, tax advisors, appraisers of company value) in the business transfer process, through train-the-trainers workshops and transfer of experience of successful European practice in solving problems in business transfer processes.

To ensure the sustainability and growth of the small and medium enterprise sector, it is necessary to pay balanced attention to all phases of venturing, from starting a venture to changing ownership / management feature of a business. For this later phase it is necessary to create an efficient national business transfer ecosystem in Croatia, which requires involvement of the line ministries and other relevant institutions responsible for the development of entrepreneurship. 


\section{REFERENCES}

Alpeza, Mirela, Grubišić, Nives, Mikrut, Martina. "Business Transfer Barometer Croatia. " CEPOR - SMEs and Entrepreneurship Policy Center, Zagreb, 2015

Business Dynamics. "Start-ups, Business Transfers and Bancruptcy." European Commission, 2011

Communication from the Commission on the transfer of small and medium-sized enterprises (98/

C93/o2)

Communication from the Commission to the Council, the European Parliament, the European Economic and Social Committee and the Committee of the Regions: „Think Small First" $A$ „Small Business Act. " for Europe, COM(2008) 394, Final

European Commission (EC). "Entrepreneurship 2020 action plan: reigniting the entrepreneurial spirit in Europe.", 2013

European Commission Recommendation of 7 December 1994 on the transfer of small and mediumsized enterprises, 94/1069/EC

European Parliament resolution of 8 September 2015 on family businesses in Europe (2014/2210(INI))

Evaluation of the implementation of the 2006 Commission communication of business transfers, final report, CSES, 2013

Final Report of the Expert Group on the Transfer of Small and Medium-Sized Enterprises, European Commission, 2002

Geerts, Anna, W. J. A. Herrings, M. J. P. M. Peek, and FrederikA. Dewall. Change of Ownership Creates New Prospects in SME Sector: A Closer Look at Business Transfers in Three European Regions. ING Economics Department, 2004

Implementing the Lisbon Community Programme for Growth and Jobs: Transfer of Businesses Continuity through a new beginning, COM (2006) 0117 Final

Isenberg, Daniel J. "How to start an entrepreneurial revolution." Harvard Business Review 88, no. 6, 2010 : $40-50$

KfW Research: KfW-Gründungsmonitor 2009, Frankfurt am Main, 2009

Schein, Edgar H. "Legitimating clinical research in the study of organizational culture." Journal of counseling \& development 71, no. 6, 1993: 703-7०8

Singer, Slavica, Anmari Viljamaa, Juha Tall, Elina Varamäki, Erno Tornikoski, Susanne Durst, Andreu Blesa, Maria Ripollés, Mirela Alpeza, Josep Xavier Soler, Mickael Buffart, Petra Mezulic. "Business transfer ecosystems: From assumption-based to evidence-based design." In RENT XXIX, Research in entrepreneurship and small business, November 18-20, 2015, Zagreb, Croatia, 2015

Singer, Slavica, Šarlija, Nataša, Pfeifer, Sanja, Oberman Peterka, Sunčica. „What makes Croatia a (non) entrepreneurial country? - GEM Croatia 2012-2015. "CEPOR - SMEs and Entrepreneurship Policy Center, Zagreb, 2015

Van Teeffelen, Lex. "Avenues to improve success in SME business transfers: reflections on theories, research and policies." Utrecht: Hogeschool Utrecht, 2012

Viljamaa, Anmari, Juha Tall, Elina Varamäki, Slavica Singer, and Susanne Durst. "Business Transfer Ecosystems and Awareness Raising Activities: Situation Analysis of Five European countries.", 2015 
Varamaki, Elina, Viljamaa, Anmari, Juha Tall and Lansiluoto, Aapo. „The Success of SME Business Transfers-Buyers' and Successors' Perspective.", 2014

Varamäki, Elina, Juha Tall and Anmari Viljamaa. "Business transfers in Finland-sellers' perspective." Proceedings of 13th Annual Concerence of the European Academy of Management, 2013: 26-29 